\title{
The Use of Keratin as Potential Biomaterial for Bio- Dental Applications
}

\author{
Lavanya Ajay Sharma, Robert M Love and Ajay Sharma* \\ School of Dentistry and Oral Health, Griffith University, Australia
}

\begin{abstract}
For a century, keratins extracted from different sources are being used for medical, cosmetic and textile applications. The excellent bioactivity and physiochemical properties of these protein extracts have recently led to the popularity of a keratin as biomaterial. Like other naturally derived biomaterials, keratins have the potential to form a defined, three-dimensional microstructure that supports cell infiltration, proliferation, and cell-guided tissue formation. In addition, the natural abundance, intrinsic biocompatibility, and mechanical durability of keratins have shown promise in the field of biomaterials in diverse biomedical applications. This mini review summarizes the biological properties, explores in brief the extraction methods and advances of keratin as a biomaterial in various biomedical and dental applications.
\end{abstract}

KEYWORDS: Keratin, Scaffold, Biomaterial, Pulp regeneration, Tissue engineering

\section{INTRODUCTION}

Dental caries is one of the most common prevalent chronic diseases in the world. Current restorative procedures remove carious tissue and replace it with a dental restorative material. However, these materials have little or no ability to remineralize teeth and maintain a good seal, leading to high failure rates [1]. Data for 166 million dental restorations in the United States suggest that more than half were replacements for failed restorations [2]. Hence, current research in dental material science is focused on developing bioactive materials regrow lost tissues based on the principles of tissue engineering. In addition, one of the main focuses in biomaterial research has been to develop scaffolds that mimic native tissue in structure and function. For this purpose, many investigators have explored the use of natural polymers due to their ability to perform very specific biochemical, mechanical and structural roles [3]. Natural polymers mimicking the extracellular matrix (ECM) offer advantages of good bioactivity, structural support and biodegradability over to synthetic polymers [4]. Several proteins have been investigated in relation to the development of naturally derived biomaterials, including collagen, albumin, gelatin, fibroin, chitosan and keratin. Of these, keratin have been promising polymers for developing scaffolds for tissue engineering purpose. Advances in the extraction, purification, and characterization of the protein have led to fabrication of several physical forms of coatings, films, foams, sponges and hydrogels [5-7]. Accordingly, a thorough literature search was carried out using different on-line databases (Ovid, Embase, PubMed, and Web of Science). Articles were selected based on keywords such as "keratin," "scaffold," "biomaterial," "regeneration," and "tissue engineering" in different combinations. Original research articles and selected review reports, published in the English language, were included. This was supplemented by a manual search and by examination of the bibliographies of the identified articles. Research letters to editor, abstract only articles, posters, unpublished articles and short communications were excluded but read to identify potential studies. This review aims primarily to present an overview of the biological properties of keratin extracts relevant to their role as a biomaterials and further, to discuss briefly different processing methods followed by a description of both the above-mentioned biopolymer advance as a potential biomaterial for dental applications.

\begin{tabular}{|c|c|}
\hline Quick Res & Griffith University, Australia \\
\hline 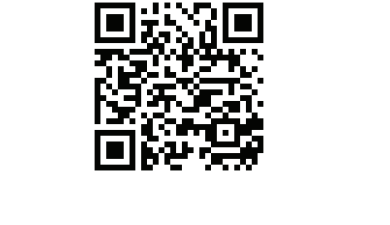 & $\begin{array}{l}\text { Received: June 16, } 2020 \text { Published: August 10, } 2020 \\
\text { How to cite this article: Lavanya AS, Robert ML, Ajay S. The Use of Keratin as Potential } \\
\text { Biomaterial for Bio-Dental Applications. 2020 - 2(4) OAJBS.ID.000204. DOI: 10.38125/ } \\
\text { OAJBS.000204 }\end{array}$ \\
\hline
\end{tabular}




\section{KERATIN AS A BIOMATERIAL}

Keratins are a class of intermediate filament proteins (IFPs) originally comprising the broad category of insoluble proteins that form the bulk of epidermal structures (i.e., hair, wool, horns, hooves and nails) [8]. Keratins can be also classified as 'hard-keratin' or 'soft-keratin' according the sulphur content [9]. "Hard' keratins have $>3 \%$ wt sulphur content and are primarily present in hair, wool, feather, nails and horns [10]. Hard keratins form ordered arrays of intermediate filaments (IFs) embedded in a matrix of cystine rich proteins and contribute to the tough structure of epidermal appendages. On the other hand, soft keratins (with a sulphur content $<3 \%$ ) consist of loosely packed bundles of IFs that helps in providing mechanical resilience [11]. Both these types of keratins have similar secondary structures but the differences in amino acid sequences are responsible for the distinct structural difference. Most notably, hard keratins contain higher content of cysteine residues in their non-helical domains that make them tougher and more durable than the epithelial soft keratins [12]. For this reason, the hard keratins have been widely investigated for their use as biomaterials for more several years now. Their structural components include outer cuticle, middle cortex and inner medulla (Figure 1). The bulk of keratins are in the cortex which can be divided into: (1) low-sulphur, "alpha" keratins which are about 50-60 \% (MW 40-60 kDa), and (2) 20-30\% high-sulphur, matrix proteins (MW 10-25 kDa). The abundant alpha keratins are the intermediate filament proteins (IFPs). Keratin IFPs are the major structural component that imparts mechanical strength, inertness and rigidity [13].

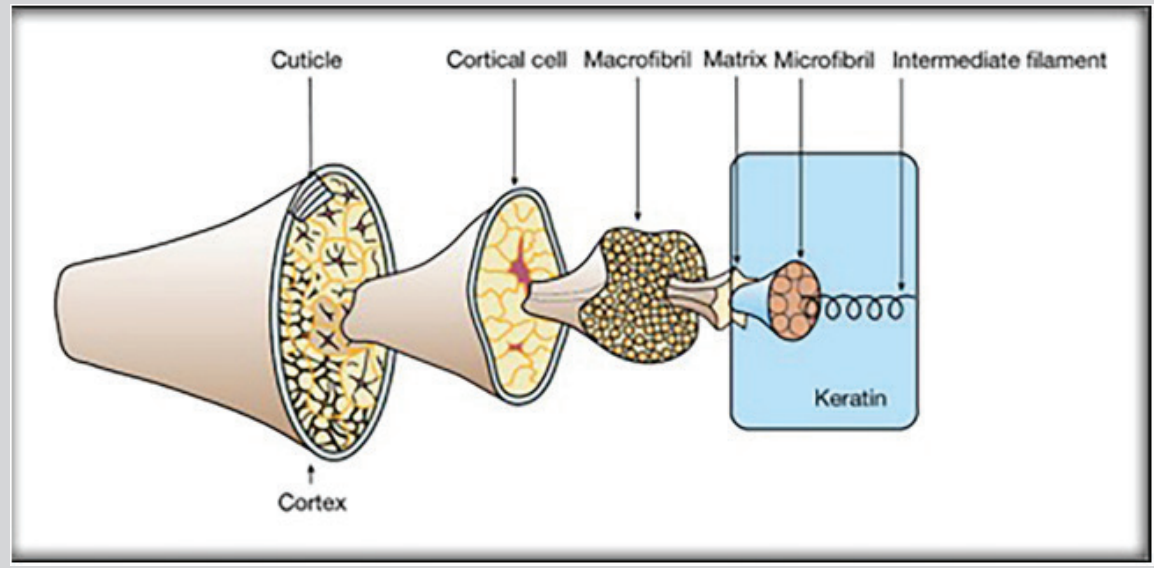

Figure 1.

Early in 1970s the research on extracted keratin proteins was focussed on developing different physical forms like films, coatings, fibres and foams. The potential use of keratin as a biomaterial in medical applications began as early as 1982 when a Japanese scientist published the first study describing the use of keratin coated, vascular grafts to control bleeding and their proven biocompatibility [14]. The main reasons for the use of keratins as a biomaterial could be listed as:

a) They are a family of structural proteins with more than 70 homologs, giving rise to an unprecedented biocompatibility

b) They have an intrinsic ability to self-assemble and polymerize into porous, fibrous scaffolds [15]

Table 1: Keratin-based products based on films/coatings.

\begin{tabular}{|c|c|c|c|c|}
\hline \multirow{2}{*}{ Ref. } & Source & Type of Study & $\begin{array}{c}\text { Experimental } \\
\text { Approach }\end{array}$ & Application \\
\hline$[18]$ & Sheep wool & $*$ & $\begin{array}{c}\text { Keratin + RGDS (blends } \\
\text { with natural polymers) }\end{array}$ & $\begin{array}{c}\text { Excellent substrates for } \\
\text { mammalian cell growth }\end{array}$ \\
\hline$[19,20]$ & Sheep wool & $*$ & $\begin{array}{c}\text { Keratin films + silk fibronin } \\
\text { (blends with natural } \\
\text { polymers) }\end{array}$ & $\begin{array}{c}\text { 个antithrobogenic properties } \\
\text { and biocompatibility }\end{array}$ \\
\hline$[21]$ & Human hair and nails & $*$ & Keratin films & $\begin{array}{c}\text { Useful materials for anti- } \\
\text { allergic actions. }\end{array}$ \\
\hline
\end{tabular}

c) They have demonstrated chemotactic and cell instructive capabilities due to the presence of cell adhesion sequences, such as glutamic acid-aspartic acid-serine (EDS), arginine-glycine-aspartic acid (RGD) and leucine-aspartic acid-valine (LDV) that mimic the extracellular matrix (ECM) $[16,17]$.

d) Implanted keratin scaffolds display minimal inflammation, support host tissue vascularization and degrade slowly

Such desirable biologic properties of keratin, plus its availability from readily renewable natural sources, have fuelled research into keratin as a biomaterial. Much has been done to establish various suitable methods for the fabrication and characterization of keratin-based new products, such as films, coatings or gels, powder, sponges, three dimensional scaffolds and fibres (Table 1-3). 


\begin{tabular}{|c|c|c|c|c|}
\hline$[22]$ & Sheep wool & $*$ & $\begin{array}{l}\text { Keratin + glycerol + chitosan } \\
\text { films (blends with natural } \\
\text { polymers); Keratin films } \\
\text { chemically cross-linked } \\
\text { with EGDE and GDE }\end{array}$ & $\begin{array}{c}\text { Improved mechanical } \\
\text { properties with } \\
\text { antibacterial activity } \\
\text { Good mechanical properties } \\
\text { and biocompatibility }\end{array}$ \\
\hline [23] & Human hair & $*$ & $\begin{array}{l}\text { Casting keratin } \\
\text { precipitation with TCA and } \\
\text { nanosuspension }\end{array}$ & $\begin{array}{l}\text { Increased cell growth on } \\
\text { nanosuspension }\end{array}$ \\
\hline$[24]$ & Human hair & * & Keratin films & $\begin{array}{l}\text { Alternative for human } \\
\text { amniotic membrane } \\
\text { for ocular surface } \\
\text { reconstruction }\end{array}$ \\
\hline$[25]$ & Human hair & * & $\begin{array}{l}\text { Films by solvent } \\
\text { evaporation }\end{array}$ & $\begin{array}{l}\text { Nail plate model for drug } \\
\text { permeation }\end{array}$ \\
\hline [26] & Sheep wool & $*$ & $\begin{array}{l}\text { Keratin + ceramides } \\
\text { membranes to simulate } \\
\text { stratum corneum }\end{array}$ & $\begin{array}{c}\text { Alternative model to } \\
\text { assay the in vitro skin } \\
\text { permeability study of small } \\
\text { molecules. }\end{array}$ \\
\hline [27] & Human hair & * & $\begin{array}{l}\text { Keratin + hydroxyapatite + } \\
\text { gentamycin coating }\end{array}$ & $\begin{array}{l}\text { Cytocompatible with } \\
\text { antibacterial activity }\end{array}$ \\
\hline [28] & Human hair & ** & Keratin films & $\begin{array}{l}\text { Good corneal } \\
\text { biocompatibility and } \\
\text { transparency }\end{array}$ \\
\hline [29] & Sheep wool & $*$ & $\begin{array}{c}\text { Keratin + PLLA } \\
\text { biocomposite films }\end{array}$ & $\begin{array}{c}\text { Potential scaffolds for } \\
\text { wound dressing and tissue } \\
\text { engineering }\end{array}$ \\
\hline$[30]$ & Human hair & * & Keratin + minocycline films & $\begin{array}{l}\text { Potential application } \\
\text { in periodontal tissue } \\
\text { regeneration }\end{array}$ \\
\hline
\end{tabular}

Abbreviations: * in vitro, ** in vivo, RGDS-Cell adhesion peptide Arg-Gly-Asp-Ser; EGDE - Ethylene glycol diglycidyl ether; GDE-Glycerol diglycidyl ether; TCA-Trichloroacetic acid; bFGF: Basic fibroblast growth factor.

Table 2: Based on powders/ sponges / fibres.

\begin{tabular}{|c|c|c|c|c|}
\hline Ref. & Source & Type of Study & $\begin{array}{l}\text { Experimental } \\
\text { Approach }\end{array}$ & Application \\
\hline$[31]$ & Sheep wool & * & Keratin sponge & $\begin{array}{c}\text { Support long-term and } \\
\text { high-density cell cultivation }\end{array}$ \\
\hline [32] & Sheep wool & * & $\begin{array}{l}\text { Hybridized keratin sponge }+ \\
\text { calcium phosphate }\end{array}$ & $\begin{array}{c}\text { Support osteoblast } \\
\text { adhesion and proliferation }\end{array}$ \\
\hline$[16]$ & Sheep wool & $*$ & $\begin{array}{c}\text { Hybridized keratin carboxy } \\
\text { sponge + BMP } 2\end{array}$ & $\begin{array}{l}\text { Localized differentiation of } \\
\text { osteoblasts }\end{array}$ \\
\hline$[6,33]$ & Sheep wool & $*$ & $\begin{array}{l}\text { Keratin sponges by CM/PL } \\
\text { method }\end{array}$ & $\begin{array}{c}\text { Scaffold with desired } \\
\text { pore size and porosity, } \\
\text { improves cell adhesion and } \\
\text { proliferation }\end{array}$ \\
\hline$[34]$ & Human hair & $*, * *$ & Keratin sponges & $\begin{array}{l}\text { Dermal substitutes for skin } \\
\text { regeneration }\end{array}$ \\
\hline [35] & Sheep wool & $* *$ & Reconstituted keratin bars & $\begin{array}{l}\text { Resorbable implant } \\
\text { material }\end{array}$ \\
\hline$[36]$ & Sheep wool & * & Keratin + PEO nanofibres & $\begin{array}{l}\text { Filter for air cleaning from } \\
\text { VOCs. }\end{array}$ \\
\hline [37] & Sheep wool & $*$ & $\begin{array}{l}\text { Keratin + silk fibronin } \\
\text { blends for membranes and } \\
\text { nanofibres }\end{array}$ & $\begin{array}{l}\text { Potential application in } \\
\text { biomedical field due to } \\
\text { biocompatibility and } \\
\text { antithrombogenicity }\end{array}$ \\
\hline$[38]$ & Sheep wool & $*$ & $\begin{array}{l}\text { Keratin-g-PEG nanoparticles } \\
\text { + doxorubicin }\end{array}$ & $\begin{array}{l}\text { Drug carriers for } \\
\text { intracellular drug delivery } \\
\text { for cancer therapy. }\end{array}$ \\
\hline [39] & Sheep wool & $*$ & Oxidized keratin powders & Improved wound healing \\
\hline$[40]$ & Sheep wool & $* *$ & $\begin{array}{l}\text { Keratin-based wound } \\
\text { dressings (keragel } \\
\text { vs keramatrix with } \\
\text { polyurethane dressings) }\end{array}$ & $\begin{array}{l}\text { Accelerated wound healing } \\
\text { and closure. }\end{array}$ \\
\hline
\end{tabular}




\begin{tabular}{|c|c|c|c|c|}
\hline$[41]$ & Human hair & $*$ & $\begin{array}{c}\text { Lyophilized keratin proteins } \\
\text { in Hepes-Tyrode buffer }\end{array}$ & $\begin{array}{c}\text { Keratin biomaterials as } \\
\text { haemostatic agents }\end{array}$ \\
\hline$[42,43]$ & Human hair & $* *$ & $\begin{array}{c}\text { Significant vasodilatory } \\
\text { effects; can be used as a } \\
\text { colloid in fluid resuscitation }\end{array}$ \\
\hline$[44]$ & Sheep wool & $*, * *$ & Reconstituted keratin bars & $\begin{array}{c}\text { Resorbable implant } \\
\text { material }\end{array}$ \\
\hline$[45,46]$ & Human hair & $* *$ & Keratin + collagen sponge & $\begin{array}{c}\text { Dermal substitutes for skin } \\
\text { regeneration }\end{array}$ \\
\hline
\end{tabular}

Abbreviations: * in vitro; ${ }^{* *}$ in vivo; BMP 2-Bone morphogenetic protein 2; CM/PL-compression-moulding/particulateleaching; PEO-Poly(ethylene oxide); VOCs-Volatile organic compounds; keratin-g-PEG-Keratin + poly(ethylene glycol); KRF-keratose resuscitation fluid.

Table 3: Based on gels.

\begin{tabular}{|c|c|c|c|c|}
\hline Ref. & Source & Type of study & $\begin{array}{l}\text { Experimental } \\
\text { Approach }\end{array}$ & Application \\
\hline [7] & Human hair & $* * *$ & Keratin hydrogel & $\begin{array}{l}\text { Neuroinductive and capable } \\
\text { of nerve regeneration in } \\
\text { mice }\end{array}$ \\
\hline [47] & Human hair & $*, * *$ & Keratin hydrogel & $\begin{array}{l}\text { Peripheral nerve } \\
\text { regeneration in mice }\end{array}$ \\
\hline [48] & Human hair & $*, * *$ & Keratin hydrogel & $\begin{array}{l}\text { Haemostatic agent in rabbit } \\
\text { model }\end{array}$ \\
\hline [13] & Human hair & $*, * *$ & Keratin hydrogel & $\begin{array}{l}\text { Excellent biocompatibility, } \\
\text { peripheral nerve } \\
\text { regeneration in rabbits }\end{array}$ \\
\hline [49] & Human hair & $* *$ & Keratin hydrogel & $\begin{array}{l}\text { Peripheral nerve repair in } \\
\text { rat model }\end{array}$ \\
\hline$[50]$ & Human hair & $*, * *$ & $\begin{array}{l}\text { Keratose hydrogel with } \\
\text { BMP-2 }\end{array}$ & $\begin{array}{l}\text { Bone regeneration in rat } \\
\text { model }\end{array}$ \\
\hline$[51]$ & Human hair & $*, * *$ & Keratin hydrogels & $\begin{array}{c}\text { Sustained release of } \\
\text { antibiotic (drug delivery) }\end{array}$ \\
\hline$[52]$ & Human hair & $*, * *$ & $\begin{array}{l}\text { Keratin hydrogels vs } \\
\text { chitosan gels }\end{array}$ & Promote wound healing \\
\hline [53] & Human hair & $* *$ & Keratin hydrogel & $\begin{array}{l}\text { Reduced ectopic bone } \\
\text { growth compared to ACS }\end{array}$ \\
\hline [54] & Human hair & $*, * *$ & Keratin hydrogel & $\begin{array}{l}\text { Potential application in } \\
\text { cardiac regeneration }\end{array}$ \\
\hline [55] & Human hair & $* *$ & $\begin{array}{l}\text { Halofuginone infused } \\
\text { keratin hydrogel }\end{array}$ & $\begin{array}{l}\text { Reduced abdominal } \\
\text { adhesions in animals }\end{array}$ \\
\hline$[56,57]$ & Human hair & $*, * *$ & Keratin hydrogels & $\begin{array}{l}\text { Haemostatic property in } \\
\text { pigs }\end{array}$ \\
\hline [58] & Human hair & $*$ & Keratin hydrogel & $\begin{array}{l}\text { Fibroblast attachment and } \\
\text { proliferation }\end{array}$ \\
\hline [59] & Sheep wool & $*$ & Keratin gel with glycerol & $\begin{array}{l}\text { mechanically stable gel that } \\
\text { supports cell adhesion }\end{array}$ \\
\hline [60] & Human hair & $*, * *$ & Keratin hydrogel & $\begin{array}{l}\text { Delivery of mouse muscle } \\
\text { progenitor cells and growth } \\
\text { factors }\end{array}$ \\
\hline [61] & Human hair & $*, * *$ & $\begin{array}{l}\text { Ciprofloxacin-loaded } \\
\text { keratose hydrogels }\end{array}$ & $\begin{array}{l}\text { Local drug therapy that } \\
\text { prevents infection and } \\
\text { supports healing following } \\
\text { cutaneous injury }\end{array}$ \\
\hline [62] & Sheep wool & Clinical study & $\begin{array}{l}\text { Keratin matrix and keratin } \\
\text { gel }\end{array}$ & Enhanced wound healing \\
\hline [63] & Sheep wool & Clinical study & Keratin gel & $\begin{array}{l}\text { Reduced scarring following } \\
\text { surgery }\end{array}$ \\
\hline [64] & Human hair & $*, * *$ & Keratin hydrogel & $\begin{array}{l}\text { Potential application in skin } \\
\text { regeneration }\end{array}$ \\
\hline
\end{tabular}




\begin{tabular}{|c|c|c|c|c|}
\hline$[65]$ & Sheep wool & $*$ & $\begin{array}{c}\text { Chemically modified keratin } \\
\text { hydrogel }\end{array}$ & $\begin{array}{c}\text { Potential cell substrate and } \\
\text { a sustained drug release } \\
\text { carrier. }\end{array}$ \\
\hline$[66]$ & Sheep wool and human hair & $*, * *$ & $\begin{array}{c}\text { Keratin hydrogels } \\
\text { prepared by electron beam } \\
\text { irradiation }\end{array}$ & Enhanced wound healing \\
\hline
\end{tabular}

Abbreviations: * in vitro; ** in vivo; BMP 2-Bone morphogenetic protein 2; ACS-Absorbable collagen sponges.

From the tables shown previously, the widespread use of keratin as a biomaterial in various biomedical applications is quite apparent. The majority of the films, castings and sponges were from wool-derived keratin IFPs whereas reconstituted hydrogels were predominantly from human hair. Van Dyke and his research group have widely investigated the role of keratin in various fields of regenerative medicine. $[48,50,67]$.

Based on the literature search, the number of patents outweighs the number of published scientific research papers which reflects the immense popularity of keratin biomaterial. The use of keratin IFPs, in the form of putty, emulsion and gel for bone tissue engineering application, biocomposites, porous keratin constructs for wound healing applications was also studied [68-70]. Woolderived, reconstituted keratin bars have shown osseoconductive properties on implantation in the long bones of sheep [71]. Since dentine resembles bone physically and chemically [72], these characteristics could be harnessed for dental tissue regeneration, especially in restorative and root canal therapy.

\section{PROCESSING METHODS OF KERATIN}

Keratins were extracted after the reduction and the oxidation of the disulphide bonds contained in their structure. The disulphide bonds of cystine form both inter and intra chains cross-links and are responsible for the greater stability and lower solubility of keratin compared with most proteins. Methods for oxidation and reduction can be found in the published literature $[73,74]$. If the extraction is carried out using an oxidant, the cysteic acid derivatives are referred to as "keratoses"; if a reductant is used, the cysteine-containing proteins are call "kerateines". However, one of the most serious shortcomings concerning these methods for extracting keratin is that a large quantity of reagents, such as acids or reductants, is consumed and cannot be recycled.

Recently, ionic liquids (ILs) have received recognition as green and promising materials for potential applications in various fields because they are typically non-volatile, non-flammable, have chemical and thermal stability, and remarkable solubility $[58,75]$. In addition, chemical-free processes such as steam explosion, superheated water and enzymatic hydrolysis has been explored [76-78].

\section{POTENTIAL OF KERATIN FOR DENTAL APPLICATIONS}

Keratin has been widely used in various biomedical applications and for regenerative medicine. However, there use in dental application has been a few. Recently, Ajay Sharma et al. $[79,80]$, studied keratin hydrogels for their potential use in dental pulp regeneration. Keratin extracted from sheep wool was fabricated as keratin hydrogels and characterized based on structural, rheological and cell viability evaluations. Furthermore, the characterized KHs were investigated for their biocompatibility by implanting of the gel into exposed rat dental pulp. The subsequent reparative/regenerative pulpal response was assessed by histological and immunohistochemical analysis. The finding of this study demonstrated that the isolated wool derived keratin was cytocompatible, enhanced odontogenic differentiation behaviour, biocompatible with reparative dentine formation and therefore, may provide an alternative biomaterial source for pulp-tissue engineering. Another study developed a biocomposite comprising Keratin-Chitosan-Tricalcium Phosphate (KCTPs) demonstrated the cytocompatibility and antimicrobial efficacy of the biocomposite making it a promising scaffold material in regenerative Endodontic therapy [81]. A study by Duncan et al. [82,83] examined the effect of Keratec Hydrogel ${ }^{\mathrm{TM}}$ on the osseointegration of titanium dental implants in an ovine femoral cancellous bone model after 4 weeks healing. Implant osseointegration was qualitatively and quantitatively assessed using histological, histomorphometric and resonance frequency analyses. Keratin hydrogel (Keratec Hydrogel $^{\mathrm{TM}}$, Keratec, Lincoln, New Zealand) improved the bone-toimplant contact (\% BIC) of titanium implants after 2, 4, 8, 12 and 16 weeks following surgery, with the greatest improvement seen at 4 weeks Bone appeared denser and more mature around the keratintreated test implants.

\section{CONCLUSION}

Keratins are promising biomaterials due to their unique chemistry afforded by their high sulphur content, excellent biocompatibility, ability to self-assemble and intrinsic cell adhesion motifs. Such advantages have led to further exploration of keratin biomaterial in the field of wound healing, tissue engineering, drug delivery systems and regenerative medicine. This narrative review clearly demonstrates the advantage of using keratins as potential biomaterial for dental applications. The use of synthetic polymers to enhance the mechanical properties may further broaden their applications. However, most of the published research involves laboratory experimentation, with some animal studies. With better understanding of keratin materials, their properties can be controlled and exploited, and hence more clinical trials will be possible.

\section{REFERENCES}

1. Ajay Sharma L, Sharma A, Dias G (2015) Advances in regeneration of dental pulp-a literature review. J Investig Clin Dent 6(2): 85-98.

2. Spencer P, Park QYE, Misra A, Bohaty BS, Viraj S, et al. (2012) Durable bonds at the adhesive/dentin interface: an impossible mission or simply a moving target? Braz Dent Sci 15(1): 4-18.

3. Ma PX (2008) Biomimetic materials for tissue engineering. Adv Drug Deliv Rev 60(2): 184-198.

4. Yuan Z, Nie H, Wang S, Hun Lee C, Li A, et al. (2011) Biomaterial selection for tooth regeneration. Tissue Eng Part B Rev 17(5): 373-388.

5. Yamauchi K, Maniwa M, Mori T (1998) Cultivation of fibroblast cells on keratin-coated substrata. J Biomater Sci Polym Ed 9(3): 259-270.

6. Katoh K, Shibayama M, Tanabe T, Yamauchi K (2004) Preparation and physicochemical properties of compression-molded keratin films. Biomaterials 25(12): 2265-2272.

7. Sierpinski P, Garrett J, Ma J, Apel P, Klorig D, et al. (2008) The use of keratin biomaterials derived from human hair for the promotion of rapid regeneration of peripheral nerves. Biomaterials 29(1): 118-128. 
8. Rouse JG (2010) A review of keratin-based biomaterials for biomedical applications. Materials 3(2): 999-1014.

9. Schweizer J, Bowden PE, Coulombe PA, Langbein L, Lane EB, et al. (2006) New consensus nomenclature for mammalian keratins. J Cell Biol 174(2): 169-174.

10. Fraser R, MacRae T, Rogers GE (1972) Keratins: their composition, structure and biosynthesis. Thomas Springfield, USA.

11. Coulombe PA, Omary MB (2002) 'Hard' and 'soft' principles defining the structure, function and regulation of keratin intermediate filaments. Curr Opin Cell Biol 14(1): 110-122.

12. Fraser RD, MacRae TP, Parry DA, Suzuki E (1986) Intermediate filaments in alpha-keratins. Proc Natl Acad Sci 83(5): 1179-1183.

13. Hill P, Brantley H, Van Dyke M (2010) Some properties of keratin biomaterials: Kerateines. Biomaterials 31(4): 585-593.

14. Ito $H$, Miyamoto $T$, Inagaki $H$, Noishiki $Y$ (1982) Biocompatibility of denatured keratins from wool. Kobunshi Ronbunshu 39(4): 249-256.

15. Thomas H, Conrads A, Phan KH, van de Löcht M, Zahn H (1986) In vitro reconstitution of wool intermediate filaments. Int J Biol Macromol 8(5): 258-264.

16. Tachibana A, Nishikawa Y, Nishino M, Kaneko S, Tanabe T et al. (2006) Modified keratin sponge: Binding of bone morphogenetic protein-2 and osteoblast differentiation. J Biosci Bioeng 102(5): 425-429.

17. Verma V, Verma P, Ray P, Ray AR (2008) Preparation of scaffolds from human hair proteins for tissue-engineering applications. Biomed Mater 3(2): 025007.

18. Yamauchi K (2003) Enhanced cell adhesion on RGDS-carrying keratin film. Mater Sci Eng C23(4): 467-472.

19. Lee K, Kong S, Park W, Ha W, Kwon I (1998) Effect of surface properties on the antithrombogenicity of silk fibroin/S-carboxymethyl kerateine blend films. J Biomater Sci Polym 9(9): 905-514.

20. Lee K, Ha W (1999) DSC studies on bound water in silk fibroin/Scarboxymethyl kerateine blend films. Polym J 40(14): 4131-4134.

21. Fujii T, Murai S, Ohkawa K, Hirai T (2008) Effects of human hair and nail proteins and their films on rat mast cells. J Mater Sci Mater Med 19(6) 2335-2342.

22. Tanabe T, Okitsu N, Yamauchi K (2004) Fabrication and characterization of chemically crosslinked keratin films. Mater Sci Eng C 24(3): 441-446.

23. Reichl S (2009) Films based on human hair keratin as substrates for cell culture and tissue engineering. Biomaterials 30(36): 6854-6866.

24. Reichl S, Borrelli M, Geerling G (2011) Keratin films for ocular surface reconstruction. Biomaterials 32(13): 3375-3386.

25. Reichl S, Müller-Goymann CC (2011) Keratin film made of human hair as a nail plate model for studying drug permeation. Eur J Pharm Biopharm 78(3): 432-440.

26. Selmin F, Cilurzo F, Aluigi A, Franzè S, Minghetti P (2012) Regenerated keratin membrane to match the in vitro drug diffusion through human epidermis. Res Pharm Sci 2: 72-78.

27. Belcarz A, Ginalska G, Zalewska J, Rzeski W, Slósarczyk A, et al. (2009) Covalent coating of hydroxyapatite by keratin stabilizes gentamicin release. J Biomed Mater Res B Appl Biomater 89(1): 102-113.

28. Borrelli M, Joepen N, Reichl S, Finis D, Schoppe M, et al. (2015) Keratin films for ocular surface reconstruction: evaluation of biocompatibility in an in-vivo model. Biomaterials 42: 112-120.

29. Aluigi A, Tonetti C, Rombaldoni F, et al. (2014) Keratins extracted from Merino wool and Brown Alpaca fibres as potential fillers for PLLA-based biocomposites. J Mater Sci 49: 6257-6269.

30. Lee H, Hwang YS, Lee HS, Choi S, Kim SJ, et al. (2015) Human hair keratinbased biofilm for potent application to periodontal tissue regeneration. Macromol Res 23: 300-308.

31. Tachibana A, Furuta Y, Takeshima H, Tanabe T, Yamauchi K (2002)
Fabrication of wool keratin sponge scaffolds for long-term cell cultivation. J Biotechnol 93(2): 165-170.

32. Tachibana A, Kaneko S, Tanabe T, Yamauchi K (2005) Rapid fabrication of keratin-hydroxyapatite hybrid sponges toward osteoblast cultivation and differentiation. Biomaterials 26(3): 297-302.

33. Katoh K, Tanabe T, Yamauchi K (2004) Novel approach to fabricate keratin sponge scaffolds with controlled pore size and porosity. Biomaterials 25(18): 4255-4262.

34. Xu S, Sang L, Zhang Y, Wang X, Li X (2013) Biological evaluation of human hair keratin scaffolds for skin wound repair and regeneration. Mater Sci Eng C 33: 648-655.

35. Peplow PV, Dias GJ, Teixeira F, Kelly RJ (2009) Tissue reaction to matrices of reconstituted keratin polymer implanted subcutaneously in sheep. J Biomed Mater Res A 89A(1): 255-265.

36. Aluigi A, Vineis C, Varesano A, Mazzuchetti G, Ferrero F, et al. (2008) Structure and properties of keratin/PEO blend nanofibres. Eur Polym J 44: 2465-2475.

37. Zoccola M, Aluigi A, Vineis C, Tonin C, Ferrero F, et al. (2008) Study on cast membranes and electrospun nanofibers made from keratin/fibroin blends. Biomacromolecules 9(10): 2819-2825.

38. Li Q, Zhu L, Liu R, Huang D, Jin X, et al. (2012) Biological stimuli responsive drug carriers based on keratin for triggerable drug delivery. J Mater Chem 22: 19964-19973.

39. Tang L, Sierra JO, Kelly R, Kirsner RS, Li J (2012) Wool-derived keratin stimulates human keratinocyte migration and types IV and VII collagen expression. Exp Dermatol 21(6): 458-460.

40. Pechter PM, Gil J, Valdes J, Tomic-Canic M, Pastar I, et al. (2012) Keratin dressings speed epithelialization of deep partial-thickness wounds. Wound Repair Regen 20(2): 236-242.

41. Rahmany MB, Hantgan RR, Van Dyke M (2013) A mechanistic investigation of the effect of keratin-based hemostatic agents on coagulation. Biomaterials 34(10): 2492-2500.

42. Nunez Jr FA (2012) Physiologic changes induced by intravenous infusion of keratin-derived resuscitation fluids on euvolemic and hypovolemic rats. Wake Forest University, USA

43. Nunez FA, Callahan MF, Trach S, Burnett LR, Kislukhin V, et al. (2013) Hemodynamic recovery after hypovolemic shock with lactated Ringer's and keratin resuscitation fluid (KRF), a novel colloid. Artif Cell Nanomed B 41(5): 293-303.

44. Peplow PV and Dias GJ (2004) A study of the relationship between mass and physical strength of keratin bars in vivo. J Mater Sci Mater Med 15(11): 1217-1220

45. Chen YH, Dong WR, Xiao YQ, Zhao BL, Hu GD, et al. (2006) Preparation and bioactivity of human hair keratin-collagen sponge, a new type of dermal analogue. Nan Fang Yi Ke Da Xue Xue Bao 26(2): 131-138.

46. Chen Y, Dong W, Chen Q Zhao B, Zou Z, et al. (2007) Biological dressing with human hair keratin-collagen sponge-poly 2-hydroxyethy methacrylate composite promotes burn wound healing in SD rats. Nan Fang Yi Ke Da Xue Xue Bao 27(11): 1621-1626.

47. Apel PJ, Garrett JP, Sierpinski P, Ma J, Atala A, et al. (2008) Peripheral nerve regeneration using a keratin-based scaffold: long-term functional and histological outcomes in a mouse model. The Hand Surg 33(9): 1541-1547.

48. Aboushwareb T, Eberli D, Ward C, Broda C, Holcomb J, et al. (2009) A keratin biomaterial gel hemostat derived from human hair: evaluation in a rabbit model of lethal liver injury. J Biomed Mater Res B Appl Biomater 90(1): 45-54

49. Lin Y-C, Ramadan M, Van Dyke M, Kokai L, Philips P, et al. (2012) Keratin gel filler for peripheral nerve repair in a rodent sciatic nerve injury model. Plast Reconstr Surg 129(1): 67-78.

50. de Guzman RC, Saul JM, Ellenburg MD, et al. (2013) Bone regeneration with BMP-2 delivered from keratose scaffolds. Biomaterials 34(6): 1644-1656 
51. Saul JM, Ellenburg MD, de Guzman RC, Van Dyke M (2011) Keratin hydrogels support the sustained release of bioactive ciprofloxacin. J Biomed Mater Res A 98(4): 544-553.

52. Poranki D, Whitener W, Howse S, Mesen T, Howse E, et al. (2014) Evaluation of skin regeneration after burns in vivo and rescue of cells after thermal stress in vitro following treatment with a keratin biomaterial. J Biomater Appl 29(1): 26-35

53. Kowalczewski CJ, Tombyln S, Wasnick DC, Hughes MR, Ellenburg MD et al. (2014) Reduction of ectopic bone growth in critically-sized rat mandible defects by delivery of rhBMP-2 from kerateine biomaterials. Biomaterials 35(10): 3220-3228.

54. Shen D, Wang X, Zhang L, Zhao X, Li J, et al. (2011) The amelioration of cardiac dysfunction after myocardial infarction by the injection of keratin biomaterials derived from human hair. Biomaterials 32(35) 9290-9299.

55. Peyton CC, Keys T, Tomblyn S, Burmeister D, Beumer JH, Holleran JL, et al. (2012) Halofuginone infused keratin hydrogel attenuates adhesions in a rodent cecal abrasion model. J Surg Res 178(2): 545-452.

56. Burnett LR, Rahmany MB, Richter JR, Aboushwareb TA, Eberli D, et al. (2013) Hemostatic properties and the role of cell receptor recognition in human hair keratin protein hydrogels. Biomaterials 34(11): 2632-2640

57. Burnett LR, Richter JG, Rahmany MB, Soler R, Steen JS, et al. (2014) Novel keratin (KeraStat ${ }^{\mathrm{TM}}$ ) and polyurethane (Nanosan $\left.®-S o r b\right)$ biomaterials are hemostatic in a porcine lethal extremity hemorrhage model. J Biomater Appl 28(6): 869-879.

58. Wang S, Taraballi F, Tan L, Ng K (2012) Human keratin hydrogels support fibroblast attachment and proliferation in vitro. Cell Tissue Res 347(3): 795-802.

59. Sando L, Kim M, Colgrave ML, Ramshaw JAM, Werkmeister JA, et al. (2010) Photochemical crosslinking of soluble wool keratins produces a mechanically stable biomaterial that supports cell adhesion and proliferation. J Biomed Mater Res A 95A(3): 901-911.

60. Tomblyn S, Pettit Kneller EL, Walker SJ, Ellenburg MD, Kowalczewski CJ, et al. (2016) Keratin hydrogel carrier system for simultaneous delivery of exogenous growth factors and muscle progenitor cells. J Biomed Mater Res B Appl Biomater 104(5): 864-879.

61. Roy DC, Tomblyn S, Burmeister DM, Wrice NL, Becerra SC, et al. (2015) Ciprofloxacin-loaded keratin hydrogels prevent pseudomonas aeruginosa infection and support healing in a porcine full-thickness excisional wound. Adv Wound Care 4(8): 457-468.

62. Batzer AT, Marsh C, Kirsner RS (2016) The use of keratin-based wound products on refractory wounds. Int Wound J 13: 110-115.

63. Jina NH, Marsh C, Than M, Singh H, Cassidy S, et al. (2015) Keratin gel improves poor scarring following median sternotomy. ANZ J Surg 85(5): 378-380.

64. Poranki D, Whitener W, Howse S, J Burnell, T Mesen, et al. (2014) Evaluation of skin regeneration after burns in vivo and rescue of cells after thermal stress in vitro following treatment with a keratin biomaterial. J Biomater Appl 29(1): 26-35.

65. Nakata R, Osumi Y, Miyagawa S, Tachibana A,Tanabe T (2015) Preparation of keratin and chemically modified keratin hydrogels and their evaluation as cell substrate with drug releasing ability. J Biosci Bioeng 120(1): 111-116
66. Park M, Shin HK, Kim BS, Kim JM, Kim S, et al. (2015) Effect of discarded keratin-based biocomposite hydrogels on the wound healing process in vivo. Mater Sci Eng C 55(1): 88-94.

67. Blanchard CR, Smith RA, Timmons SF (1999) Keratin-based hydrogel for biomedical applications and method of production. Google Patents. US patent US5932552.

68. Ali MA, Hassan MM, Kelly RJ, (2010) Composite materials containing keratin. US patent US7767756.

69. Ali MA, Kelly RJ, Marsh C, Sigurjonsson GF, Smith RA (2008) Porous keratin constructs, wound healing assemblies and methods using the same. Google Patents. US patent US20080317826.

70. Ali MA, Kelly RJ, Marsh C and Sigurjonsson GF (2012) Porous keratin construct and method of making the same. US patent US8124735 B2. Keraplast technologies Ltd.

71. Dias GJ, Mahoney P, Hung NA, Sharma LA, Kalita P, et al. (2017) Osteoconduction in keratin-hydroxyapatite composite bone-graft substitutes. J Biomed Mater Res B Appl Biomater 105(7): 2034-2044.

72. Kumar GS (2014) Orban's Oral Histology \& Embryology. Elsevier Health Sciences APAC, USA.

73. Buchanan JH (1977) A cystine-rich protein fraction from oxidized alphakeratin. Biochem J 167(2): 489

74. Yamauchi K, Yamauchi A, Kusunoki T, Kohda A, Konishi Y (1996) Preparation of stable aqueous solution of keratins, and physiochemical and biodegradational properties of films. J Biomed Mater Res 31(4): 439-444.

75. Hameed N, Guo Q (2010) Blend films of natural wool and cellulose prepared from an ionic liquid. Cellulose 17: 803-813.

76. Tonin C, Zoccola M, Aluigi A, Varesano A, Montarsolo A, et al. (2006) Study on the conversion of wool keratin by steam explosion. Biomacromolecules 7(12): 3499-3504.

77. Yin J, Rastogi S, Terry AE, Popescu C (2007) Self-organization of oligopeptides obtained on dissolution of feather keratins in superheated water. Biomacromolecules 8(3): 800-806.

78. Gupta R, Ramnani P (2006) Microbial keratinases and their prospective applications: an overview. Appl Microbiol Biotechnol 70(1): 21-33.

79. Ajay Sharma L, Ali MA, Love RM, Wilson MJ, Dias GJ (2016) Novel keratin preparation supports growth and differentiation of odontoblast-like cells. Int Endod J 49(5): 471-482.

80. Ajay Sharma L, Love RM, Ali MA, Ajay S, MAcari A, et al. (2017) Healing response of rat pulp treated with an injectable keratin hydrogel. Journal of Applied Biomaterials \& Functional Materials 15: e2440e250.

81. Ramawarrier A (2016) Sheep wool keratin based biocomposite scaffold for potential use in regenerative endodontics. USA.

82. Duncan WJ, Greer PFC, Lee M-H, Loch C, Gay JHA (2018) Wool-derived keratin hydrogel enhances implant osseointegration in cancellous bone. J Biomed Mater Res B Appl Biomater 106(6): 2447-2454.

83. Campbell DI, Duncan WJ (2014) The effect of a keratin hydrogel coating on osseointegration: an histological comparison of coated and noncoated dental titanium implants in an ovine model. J Maxillofac Oral Surg 13(2): 159-164. 